DOI: $10.20472 /$ IAC.2018.035.026

\author{
ERCAN KOCAYÖRÜK \\ Çanakkale Onsekiz Mart Üniveristy, Turkey \\ SALIH ZEKI GENÇ \\ Çanakkale Onsekiz MArt Üniversity, Turkey \\ TUGAY TUTKUN \\ Çanakkale Onsekiz Mart University, Turkey
}

\title{
A CROSS-CULTURAL EXAMINING THE RELATIONSHIP BETWEEN CONTROLLING AND AUTONOMY-SUPPORTIVE PARENTING ON WELL-BEING OF ADOLESCENTS
}

\begin{abstract}
:
The aim of the this study is to examine the effect of parental suppoertiveness and psychological control on relational self and well-being. Controlling parents are characterized by a lack of interpersonal bound-aries between their members, which hinders the development of children's healthy individuation. The findings of study showed that PC may render negative affect and feeling of adolescents. In this perspective it can be suggested that the need for parenting programs aimed at preventing the use of psychological control among parents of adolescents of all ages, and adolescent programs aimed at reducing the negative affect and emotions. It is important to educate parents that psychological control is a universally negative parenting strategy and to help parents identify and reduce the use of such behaviors.
\end{abstract}

\section{Keywords:}

Psychological control, Parental supportiveness, well-being 